\title{
SPERMAGGLUTININ FORMATION IN MALE RATS BY SUBCUTANEOUSLY INJECTED SYNGENEIC EPIDIDYMAL SPERMATOZOA AND BY VASOLIGATION OR VASECTOMY
}

\author{
Ph. RÜMKE AND M. TITUS \\ Department of Immunology, The Netherlands Cancer Institute, \\ Sarphatistraat 108, Amsterdam, The Netherlands \\ (Received 15th November 1968, revised 10th July 1969)
}

\begin{abstract}
Summary. Macroscopic agglutination of rat epididymal spermatozoa was a sensitive reproducible test for the detection and titration of spermagglutinins in rat sera.

Naturally occurring spermagglutinins were occasionally found, especially in aged males, but never in titres higher than 20.

Inbred male rats, subcutaneously injected with large quantities of syngeneic, unwashed epididymal spermatozoa without adjuvant produced spermagglutinins. The highest titre (2560) was found in the serum of a rat 7 days after injection of $1.5 \times 10^{9}$ spermatozoa.

Significant spermagglutinin formation was found after unilateral vasoligation in some $(2 / 7)$ rats and unilateral vasectomy in all $(8 / 8)$ rats. The antibody stimulation tended to cease after removal of the testis and epididymis of the operated side.

The presence of spermagglutinins in the serum neither interfered with spermatogenesis nor necessarily with the animal's fertility.
\end{abstract}

\section{INTRODUGTION}

Infertility due to auto-immunity to spermatozoa occurs in animals under experimental, and in the human male under natural, conditions. In experimental systems, immunization with spermatozoa or testis extracts, incorporated in complete Freund's adjuvant, leads to an auto-allergic orchitis which manifests itself clinically in the disappearance of spermatozoa from the ejaculate and aspermatogenesis (reviewed by Voisin \& Toullet, 1968). When the same antigens are injected with incomplete Freund's adjuvant (i.e. without the killed mycobacteria), the animals will only develop antibodies against spermatozoa, but their testes will not be affected. It is surprising that there are no reports concerning the reproductive function of animals with antibodies against spermatozoa but with normal testis histology; the more so since it is known that, in the case of the infertile male patient, auto-antibodies against spermatozoa can render them incapable of fertilization, and this often occurs in 
patients with normal testicular histology and a normal production of spermatozoa (Rümke \& Hellinga, 1959; Fjällbrant, 1965, 1968). The disparity between what is known about the experimental animal and about the human patient is emphasized by the fact that spermagglutinins are the antibodies least looked for in animals immunized with spermatozoa or testis extracts whereas in men spermagglutinins, and also immobilizing antibodies, play an important rôle in infertility.

The history and physical examination of such patients often suggest that some of their spermatozoa were or are continuously resorbed either in the epididymis or rete testis, as, for example, when a patient has an obstruction in his efferent ducts (Rümke, 1965). Various reports on series of patients with obstructions reveal that about a quarter of such individuals have spermagglutinins in their serum (Phadke, 1964; Rümke, 1967). Information about sperm . auto-antibody (especially spermagglutinin) formation after vasoligation in animals is limited. Only Bratanov, Dikov \& Popova (1964) claimed that, after unilateral ligation of the vas deferens in the rabbit, ram and bull, spermagglutinins may develop.

The present study aimed to show that: (1) the macroscopic agglutination technique as described by Kibrick, Belding \& Merrill (1952), and used by us for the titration of spermagglutinins in human sera, could well be used in a modified form for the detection and titration of spermagglutinins in rat serum against rat spermatozoa; (2) male rats injected with large amounts of epididymal spermatozoa of the same strain develop spermagglutinins; (3) vasoligation or vasectomy in the rat can lead to the formation of auto-spermagglutinins as in man; and (4) serum-spermagglutinins, as such, do not interfere with spermatogenesis and do not necessarily impair the fertility of the animals.

\section{MATERIALS AND METHODS}

Rats

Male rats of the inbred (sixty generations) Wistar line, called R-strain, of the stock of the Netherlands Cancer Institute were used for all experiments. All procedures were performed in a room with a constant temperature of $30^{\circ} \mathrm{C}$.

\section{Sperm suspensions}

Epididymal spermatozoa were collected from rats exsanguinated under ether anaesthesia by dissecting the epididymis and vas deferens free of blood vessels, and mincing them with scissors in medium in a watch glass. Motile spermatozoa swam out of the minced pieces into the medium, giving it a milky appearance within a few minutes. This sperm suspension was transferred through a widemouth pipette (care being taken to avoid air bubbles) into a measuring glass where it was pooled with the suspensions derived from other rats. The medium was added to the pool so that the final sperm concentration was of the order of $10^{7}$ spermatozoa $/ \mathrm{ml}$, and such a suspension could be used for the spermagglutination test. The medium, a modified Hanks's solution, consisted of $8 \mathrm{~g}$ $\mathrm{NaCl}, 0.4 \mathrm{~g} \mathrm{KCl}, 1 \mathrm{~g}$ glucose, $0.5 \mathrm{ml} \mathrm{MgSO}{ }_{4} .7 \mathrm{H}_{2} \mathrm{O} 40 \%, 0.5 \mathrm{ml} \mathrm{KH_{2 }} \mathrm{PO}_{4}$ 
$12 \%, 0.5 \mathrm{ml} \mathrm{Na}{ }_{2} \mathrm{HPO}_{4} .2 \mathrm{H}_{2} \mathrm{O} 12 \%, 4 \mathrm{ml} \mathrm{NaHCO} 3 \%$, and $5 \mathrm{~g}$ bovine lactalbuminhydrolysate, with water added to make 1 litre; the $\mathrm{pH}$ was 6.7 to 6.9.

When spermatozoa were to be used for immunization procedures, they were suspended in phosphate-buffered saline solution $(\mathrm{pH} 7 \cdot 4)$ instead of the modified Hanks's solution.

\section{Spermagglutination test}

The spermagglutination test was performed (without using gelatin) according to a modification of the technique of Kibrick, Belding \& Merrill (1952). The rat sera to be tested were heated for $30 \mathrm{~min}$ at $56^{\circ} \mathrm{C}$, since unheated serum immobilizes spermatozoa nonspecifically. Dilutions were made with the same medium that was used to suspend the spermatozoa. Volumes of $0.3 \mathrm{ml}$ were placed in small glass tubes with internal diameters of $6 \mathrm{~mm}$. The same volume of the stock sperm suspension $\left(10^{7}\right.$ spermatozoa $\left./ \mathrm{ml}\right)$ was added, and serum and spermatozoa were mixed as gently as possible. The tubes were left in the same room at $30^{\circ} \mathrm{C}$, and readings were taken macroscopically after 1,2 and $3 \mathrm{hr}$. The granular appearance of the agglutination reaction can be clearly distinguished from the homogeneous appearance of the negative reaction.

\section{Immunization procedures}

Rats to be immunized with syngeneic spermatozoa were injected subcutaneously with different amounts of unwashed epididymal spermatozoa suspended in phosphate-buffered saline. In a few experiments, complete and incomplete Freund's adjuvant (Difco) were used. The immunization schedules are given under the heading of the experiments.

\section{Vasoligation and vasectomy}

These surgical procedures were always performed on only one side (the left). The instruments were clean, but not sterile. After incising the cutaneous and muscular layers on the ventral surface along the penis, the vas deferens was dissected free of blood vessels for approximately $1 \mathrm{~cm}$. For a vasectomy, that part which had been dissected free was cut out and removed, the remaining ends not being closed. For a vasoligation, the same operation was performed, except that ligatures were first placed on the vas at either side of the two places where the vas was to be transected.

\section{Serum}

After general anaesthesia with ether, rats were bled to death from the carotid artery. When the animal was kept alive, 1 to $2 \mathrm{ml}$ blood was drawn from an orbital vein. After clotting and centrifugation, serum was separated and stored at $-20^{\circ} \mathrm{C}$.

\section{Fertility test}

The male to be tested was placed with a virgin female rat which, according to the vaginal smear pattern, exhibited regular oestrous cycles. If, after 32 days, the female was not yet pregnant, she was replaced by another female 
of proven fertility. The male rat was considered to be sterile when the second female also did not become pregnant after 32 days.

\section{EXPERIMENTS AND RESULTS}

Experiments to standardize the spermagglutination test

The macroscopic spermagglutination test, as described by Kibrick et al. (1952), is routinely used in this laboratory for the detection of spermagglutinins in human sera. The same technique using rat epididymal spermatozoa was

TABLE 1

$$
\begin{gathered}
\text { EFFEGTS OF SPERM CONCENTRATION AND TEMPERATURE ON SPERM- } \\
\text { AGGLUTINATION }
\end{gathered}
$$

\begin{tabular}{c|c|ccc|ccc}
\hline $\begin{array}{c}\text { Incubation } \\
\text { temp. }\end{array}$ & \multicolumn{2}{|c|}{$\begin{array}{c}\text { Sperm conc. } \\
\times 10^{6} / \mathrm{ml}\end{array}$} & \multicolumn{3}{|c|}{ Normal serum dilutions } & \multicolumn{3}{|c}{ Immune serum dilutions } \\
$1: 90$ & $1: 270$ & $1: 810$ & $1: 90$ & $1: 270$ & $1: 810$ \\
\hline $20^{\circ} \mathrm{C}$ & 20 & \pm & \pm & \pm & \pm & \pm & \pm \\
& 10 & - & - & - & - & - & - \\
& 5 & - & - & - & - & - & - \\
$27^{\circ} \mathrm{C}$ & $2 \cdot 5$ & - & - & - & - & - & \pm \\
& 20 & \pm & \pm & \pm & \pm & \pm & \pm \\
& 10 & - & - & - & + & + & - \\
$30^{\circ} \mathrm{C}$ & 5 & - & - & - & + & \pm & - \\
& $2 \cdot 5$ & - & - & - & + & - & \pm \\
& 20 & \pm & \pm & \pm & \pm & \pm & \pm \\
$37^{\circ} \mathrm{C}$ & 10 & - & - & - & + & + & \pm \\
& 5 & - & - & - & + & + & - \\
& $2 \cdot 5$ & - & - & - & + & + & \pm \\
& 10 & \pm & \pm & \pm & \pm & \pm & \pm \\
& 5 & - & - & - & + & - & - \\
& $2 \cdot 5$ & - & - & - & \pm & - & - \\
\hline
\end{tabular}

tried for the testing of rat sera, but, in contrast to human spermatozoa, rat spermatozoa were found to lose their motility in phosphate-buffered glucose gelatin solution, and were not therefore suitable for the spermagglutination test since this always needs spermatozoa of good motility. However, when this medium was replaced by a modified Hanks's solution (see 'Materials') without gelatin, the rat spermatozoa retained their motility for several hours, and were easily agglutinated by a rat antiserum against spermatozoa, whereas the normal sera of untreated young adult rats did not agglutinate the spermatozoa, provided they were inactivated by heating to $56^{\circ} \mathrm{C}$ for $30 \mathrm{~min}$. Unheated sera showed immobilization and/or pseudoagglutination.

For further standardization experiments, a normal serum and a serum sample from a rat immunized with epididymal rat spermatozoa were used. Agglutination tests were performed at different incubation temperatures and with sperm suspensions of different concentrations (see Table 1).

With a stock sperm suspension of $2 \times 10^{7}$ spermatozoa $/ \mathrm{ml}$, the readings were difficult since with all serum dilutions and temperatures the macroscopic appearance of the control showed a rather broken, as contrasted with a homo- 
geneous, turbidity. With sperm concentrations of $1 \times 10^{7} / \mathrm{ml}$ or less, the controls were homogeneous, indicating total absence of macroscopic agglutination. The immune serum readings were best with a concentration of $1 \times 10^{7} / \mathrm{ml}$. The titre was higher with that concentration than with 0.5 and $0.25 \times 10^{7} / \mathrm{ml}$.

The incubation temperature of $30^{\circ} \mathrm{C}$ gave the best results. This was also to be expected from the fact that, at $30^{\circ} \mathrm{G}$, the motility of the spermatozoa lasted the longest. Therefore, all further tests were performed at $30^{\circ} \mathrm{C}$ with a suspension concentration of $10^{7}$ spermatozoa $/ \mathrm{ml}$.

Readings were made after 1, 2 and $3 \mathrm{hr}$ since weak spermagglutinating sera could show agglutination only after $3 \mathrm{hr}$, but stronger sera acted in such a short time that, after $1 \mathrm{hr}$, the clumps of spermatozoa settled down in the bottom of the tube, making the reading less clear. Therefore, it seemed advisable to take readings also after 1 and $2 \mathrm{hr}$.

Sera of young adult male rats generally did not show agglutination within $3 \mathrm{hr}$.

That the test was capable of yielding highly reproducible results was shown by seven spermagglutinating sera which were re-tested after an interval of about 5 months, during which the sera were kept at $-20^{\circ} \mathrm{C}$. The titres of the first and second tests with each serum were 1280-1280, 1280-640, 640-640, $640-640,320-320,320-320$ and $40-40$, respectively. The titres at the second test were read by one of us (M.T.) without knowledge of the results of the first test.

\section{Naturally occurring spermagglutinins in male rats}

For the immunization experiments described below, the sera of thirty-six animals were tested when they were $3 \frac{1}{2}$ months old, several months before the experiment started. One of these animals possessed spermagglutinins in the serum in a titre of 20; the others were all negative at a dilution of 1:5. Two out of eight untreated control animals for another experiment (auto-immunization by vasoligation or vasectomy) had low titres ( 5 and 10) when they were nearly 1 year old. In the beginning of this experiment, none of the twentythree male rats possessed spermagglutinins in their serum. In another series, sera were tested from fifteen male rats 283 to 330 days old. The sera of six rats in a dilution of $1: 5$ were negative, three were positive with a titre of 5 , and six with a titre of 10 .

It can thus be stated that titres of 40 or higher never occurred under natural conditions in seventy-four male rats of various ages.

\section{Immunization experiments}

Seven-month-old male rats were given four subcutaneous injections with syngeneic epididymal spermatozoa according to the scheme given in Text-fig. 1 . Spermagglutinin titres were detected in blood drawn 7, 14, 21, 28 and 47 days after the first injection. As shown in Text-fig. 1, the six rats injected with the highest amount, i.e. 1.5 to $2.3 \times 10^{9}$ spermatozoa/rat, responded within 7 days after one injection with titres of 640 to 2560. The second group, which received ten times less than the first, responded less vigorously. Only one animal attained a titre of 640 , but this animal had a titre of 20 before the 


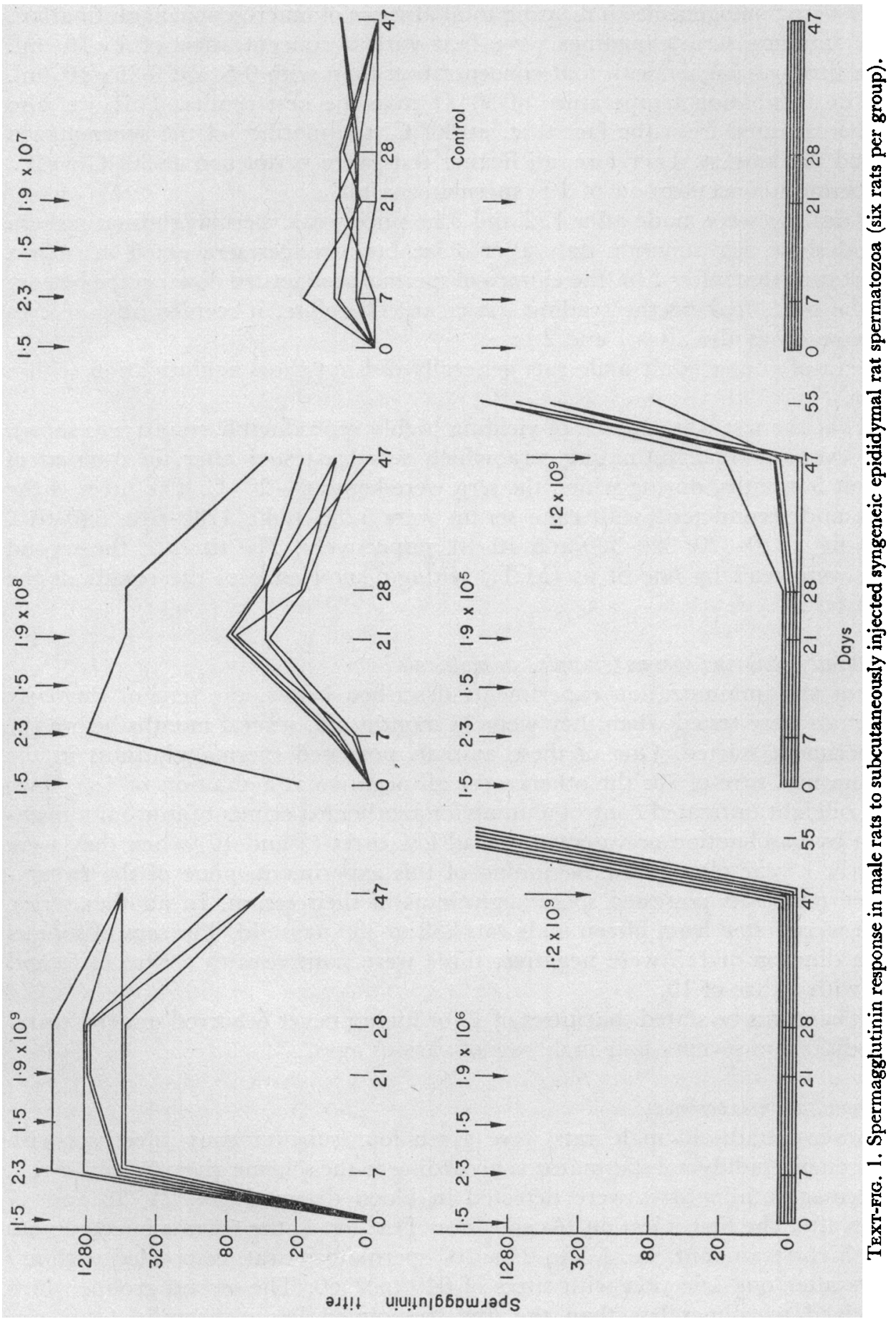


experiment started; the others did not reach higher than 80 on the 21 st day after having received three injections. All titres declined in the 4 weeks after the last injection. The rats which received $10^{7}$ spermatozoa/injection never developed titres higher than 20. The rats of the other groups did not respond at all.

Since the question arose as to whether injection of low doses rendered the animals tolerant, the rats which had received $10^{6}$ and $10^{5}$ spermatozoa/injection were injected with $10^{9}$ spermatozoa after 47 days. All rats had spermagglutinin titres 7 days later which were as high as those of the first group which received $10^{9}$ spermatozoa on the first day of the experiment. From this, it follows that doses of $10^{6}$ and $10^{5}$ spermatozoa were too low to stimulate spermagglutinin formation, and that the animals were not rendered tolerant by these low doses.

\section{Auto-immunization by unilateral vasoligation or vasectomy}

Unilateral vasoligation was performed on seven rats and unilateral vasectomy on eight rats. Eight control rats underwent a sham operation. All rats were of the same age and strain. Blood was taken just before, and 113, 165 and 215 days after, operation. As shown in Text-fig. 2, two of the eight control rats had, on the 215th day, spermagglutinins in titres of 5 and 10, similar to titres acquired spontaneously with age. However, out of the seven vasoligated animals, two developed high spermagglutinin titres (1280 and 640 on the 215 th day), while five had low titres (not higher than 10). All eight vasectomized rats developed titres ranging from 40 to 1280 (five of them had a titre of 320 or higher).

Thus two of seven vasoligated rats and all eight vasectomized rats developed spermagglutinins in titres higher than were ever encountered under natural conditions. It is striking that more vasectomized than vasoligated animals reacted, presumably because the spermatozoa of the vasectomized rats were free to flow into the peritoneal cavity.

All rats involved in this experiment were proved to be fertile within the first 10 days after the operation, showing that the non-operated side was functionally normal. On the 197th day, they were tested again for their capacity to fertilize. Of the two vasoligated rats with high titres, the one with a spermagglutinin titre of 1280 on the 215th day appeared to be fertile, while the other, with a titre of 640 , was sterile. The vasoligated rats with low titres were all fertile, as was the vasectomized rat with a titre of 1280 ; four other fertile rats had titres of $320,160,80$ and 40 . Three rats, all with titres of 640 on the 215 th day, were sterile. These observations show that the autospermagglutinins as such are not necessarily impairing the fertility of the male rat. If continuous resorption of spermatozoa on the operated side was responsible for a lasting spermagglutinin titre, a hemicastration on the operated side would lead to a decrease of the titre. Four animals of the group of the vasectomized rats were, therefore, hemicastrated and four others of the same group had a sham operation (laparotomy). For the hemicastration, animals with titres of 1280, 640, 640 and 160, and for the sham operation, animals with titres of 640, 320, 80 and 40, on the 215th day, were chosen. Hemicastration was carried out on the same 
side of the abdomen as the vasectomy, the testis was pulled into the peritoneal cavity, the blood vessels were ligated, and the testis, epididymis and vas deferens peripheral to the vasectomy were extirpated.
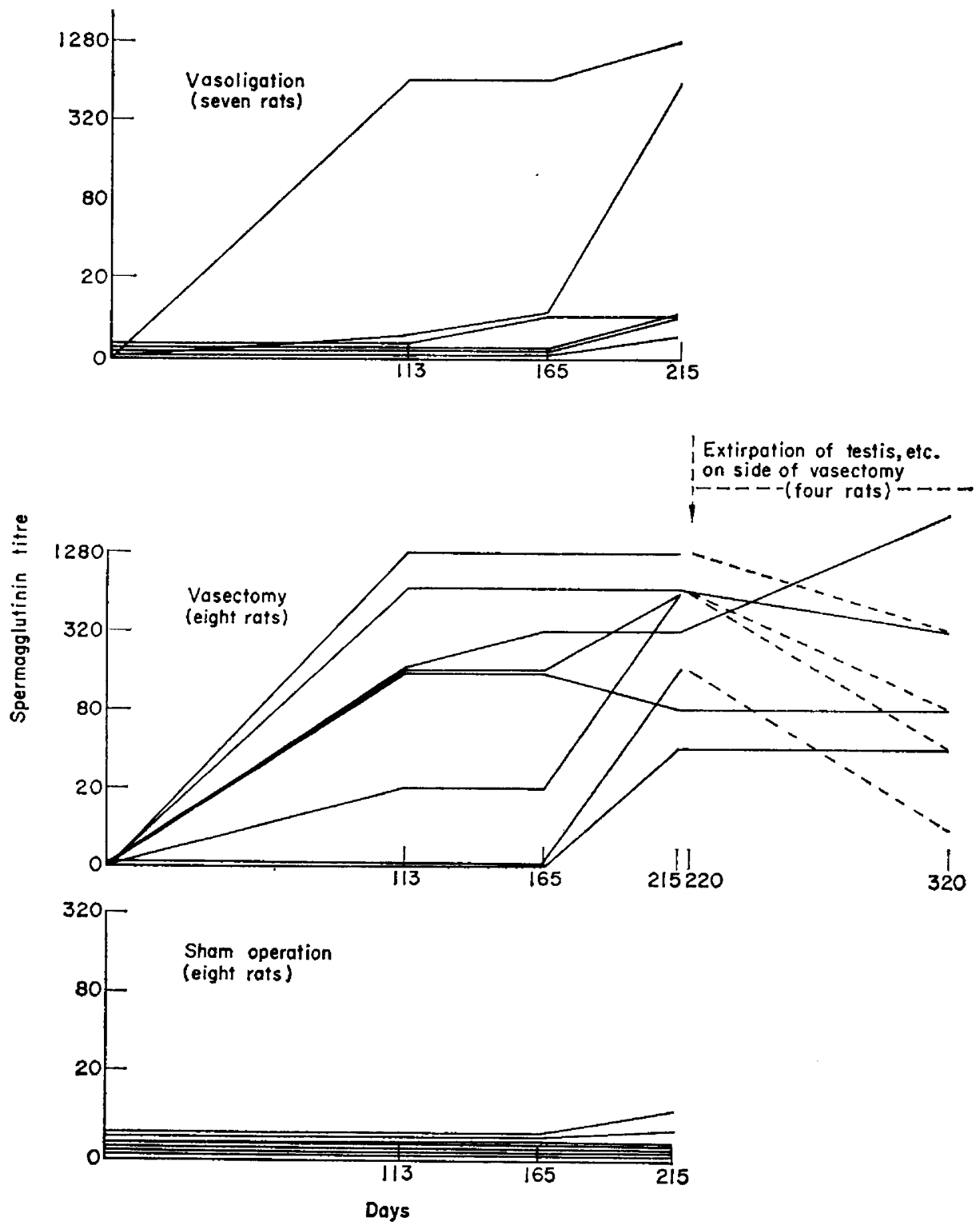

TexT-FIG. 2. Spermagglutinin formation after vasoligation or vasectomy.

Animals were bled 95 days after the operation. All four hemicastrated animals showed a significant drop in titre (1280 to 320,640 to 80,640 to 40 , 160 to 10$)$. The sham-operated rats did not show any significant decrease in titre $(640$ to 320,320 to 2560,80 to 80,40 to 40$)$. The results suggest that 
removal of the source of antibody stimulation leads to a gradual disappearance of the antibodies.

Since only two out of the seven vasoligated rats developed spermagglutinins in high titres, the other five might have been rendered tolerant. This possibility was tested by injecting all seven animals subcutaneously with $1.2 \times 10^{6}$ spermatozoa on the 215th day. Eight days later, the titres were changed respectively from 1280 to 640,640 to 40,10 to 1280,10 to 320,10 to 320,5 to 1280 and 0 to 640 . With the exception of the second animal, which showed a sharp decrease in titre (for which we have no explanation), all animals appeared to react to the relatively small dose of $10^{6}$ spermatozoa, and thus were not tolerant. On the contrary, the low titres apparently reflected a state of continuous low stimulation, and the dose of $10^{6}$ spermatozoa, which was insufficient to stimulate spermagglutinin formation in non-treated animals (see Text-fig. 1), acted here, presumably, as a booster injection initiating a secondary response.

\section{Pathology of the vasoligated or vasectomized rats}

The vasoligated rats were killed on the 231 st day, 16 days after they received the injection of $10^{6}$ spermatozoa. The testis on the non-operated right side was macroscopically normal or even slightly enlarged in all seven animals; the epididymis contained normal motile spermatozoa on that side, and microscopically too, these testes showed no abnormalities.

Two animals that both possessed titres of 10 on the 215th day had normal testes on the operated left side, and the vas and epididymis contained normal motile spermatozoa. The blind end of the vas deferens ended in a 'pocket' built up by the peritoneum. It contained sperm tails, which had apparently leaked through the ligated and necrotic vas. All other rats of this group had signs of degeneration of the left testis, and the vas and epididymis contained headless and immotile spermatozoa.

The testes of the vasectomized animals were either investigated at the time when four of the animals were hemicastrated, or after the experiment when they had a sham operation. In all eight cases, the right testes were normal or slightly enlarged with normal motile spermatozoa in the right vas. The left testes all showed signs of degeneration, always with headless immotile spermatozoa in the vas. Histologically there was considerable degeneration of the testes on the left side.

The testes of the animals immunized with spermatozoa without Freund's adjuvant all appeared to be normal, with normal spermatozoa in the vas when they were killed 78 days after the beginning of the experiment. The four rats immunized with spermatozoa emulsified in Freund's adjuvant had testes with histological signs of degeneration on both sides ( 72 days after the first and only injection of spermatozoa in complete Freund's adjuvant).

\section{DISCUSSION}

The results show that the macroscopic agglutination technique as described by Kibrick et al. (1952) is a very suitable technique for the detection of anti- 
bodies against spermatozoa, e.g. spermagglutinins in rat serum. Prerequisites are the gentle handling of the epididymal spermatozoa, an appropriate medium and a constant temperature of $30^{\circ} \mathrm{C}$. It is a sensitive technique and easily reproducible. The highest titre ever found with a serum of an immunized male rat was 2560 .

Occasionally, the sera of untreated male animals (especially when they were old) possessed spermagglutinins, but never in titres higher than 20 .

The immunization experiments showed that male rats can be immunized with syngeneic epididymal spermatozoa, even without the use of an adjuvant, provided that a sufficiently high dose is used. Immunization with epididymal spermatozoa seems to be a matter of quantity rather than quality since this finding has demonstrated the auto-antigenicity of epididymal spermatozoa before they mix with the secretions of the adnexal glands.

The experiments with unilaterally vasoligated or vasectomized rats show that spermatozoa, when abnormally resorbed, can induce the formation of spermagglutinins. However, not all vasoligated animals developed spermagglutinins (at least, not in high titres). Those animals with the lower titres, or even without detectable spermagglutinins, developed high titres 1 week after they were injected subcutaneously with $10^{6}$ spermatozoa although this dose had been found to be too low to stimulate spermagglutinin formation in normal, untreated animals. Thus, it seems reasonable to assume that this dose is enough to stimulate high agglutinin production in an animal already 'primed' by continuous resorption of low doses of spermatozoa.

That the vasoligated animals responded diversely might be the result of variations in two factors. In the first place, since the operations were not carried out under sterile conditions, it could well be that bacterial infections were potentiating an antibody response to the sperm antigens. On the other hand, infections and vascular lesions could disturb the spermatogenesis of the testis on the affected side when too few spermatozoa might be resorbed to stimulate spermagglutinin formation. The validity of these suppositions was not further investigated in the current experiments.

An important finding was that male rats remained fertile with high titres (1280) of spermagglutinins. The agglutinins apparently did not enter the control testis which remained normal histologically, and they either did not enter the seminal fluid, or entered but failed to impair the fertilizing ability of the spermatozoa. It is not known if the failure of the agglutinins to enter the seminal plasma is a feature of the species or if the antibody globulin was nonpenetrating IgM. In man, IgG and IgA are found in seminal plasma, but not IgM.

Mancini, Vilar, Alvarez \& Seiguer (1964) claimed that, in the rat, serum proteins may diffuse from the blood into the tubular lumini of the testis. They did not state, however, whether there is a difference in this respect between macroglobulins and other globulins. Possibly spermagglutinins in our fertile animals are IgM antibodies, that would leave the testis unaffected if they were unable to diffuse from the blood.

It is surprising how little is known about the presence of sperm antibodies in semen of animals known to have such antibodies in the blood following auto- 
immunization procedures. The observation of Wentworth \& Mellen (1964) that Japanese quails immunized with testicular spermatozoa had agglutinated spermatozoa in the vas deferens, is unique in this respect.

A few rats with spermagglutinins were sterile in spite of repeated attempts to prove their fertility, and in spite of proven fertility just after vasoligation or vasectomy. Their testes on the non-operated sides were normal. It seems possible that, in these cases, sperm antibodies do reach the seminal fluid. But no further attempt has been made to characterize the spermagglutinins according to their antibody type.

Finally, the finding that the spermagglutinin titre decreased after extirpation of the affected epididymis and testis illustrated that a continuous resorption of sperm antigens seemed necessary for a lasting spermagglutinin titre.

\section{ACKNOWLEDGMENTS}

This investigation received financial support from the World Health Organization.

\section{REFERENCES}

Bratanov, K., Dikov, V. \& Popova, Y. (1964) Sur la formation des auto-spermo-anticorps chez les reproduceurs. C.r. Acad. bulg. Sci. 17, 1117.

FJällbRANT, B. (1965) Immunoagglutination of sperm in cases of sterility. Acta obst. gynec. scand. 44, 474.

FJällbrant, B. (1968) Sperm antibodies and sterility in men. Acta obst. gynec. scand. 47, Suppl. 4, 38.

Kibrick, S., Belding, D. L. \& Merrill, B. (1952) Methods for the detection of antibodies against mammalian spermatozoa. Fert. Steril. 3, 419 and 430 .

Mancini, R. E., Vilar, O., Alvarez, B. \& Seiguer, A. C. (1964) Extravascular and intratubular diffusion of labeled serum proteins in the rat testis. 7. Histochem. Cytochem. 13, 376.

Phabke, A. M. (1964) Fate of spermatozoa in case of obstructive azoospermia and after ligation of vas deferens in man. 7. Reprod. Fert. 7, 1.

Rümke, PH. (1965) Autospermagglutinins: A cause of infertility in men. Ann. N.Y. Acad. Sci. $124,696$.

Rümke Pr. (1967) Sperm-agglutinating autoantibodies in relation to male infertility. Proc. R. Soc. Med. 61, 275.

Rümke, Ph. \& Hellinga, G. (1959) Auto-antibodies against spermatozoa in sterile men. Am. J. clin. Path. 32, 357.

Voisın, G. A. \& Toullet, F. (1968) Etude sur l'orchite aspermatogénétique autoimmune et les autoantigènes de spermatozoïdes chez le cobaye. Annls Inst. Pasteur, Paris, 114, 727.

Wentworth, B. C. \& MELlen, W.J. (1964) Active immunity induced and spermatogenesis suppressed by testicular antigen in the male Japanese quail. 7. Reprod. Fert. 8, 215. 